\title{
Production and characterization of cellulase from mushroom (Pleurotus ostreatus) for effective degradation of cellulose
}

\author{
Beyisa Benti Diro 1, Tadessa Daba ${ }^{2}$ and Temam Gemeda Genemo 3,* \\ ${ }^{1}$ Department of Biology, Dilla University, Dilla, Ethiopia. \\ ${ }^{2}$ Agricultural Biotechnology Research, EIAR, Addis Ababa. \\ ${ }^{3}$ Department of Biotechnology, Wachemo university, Hossana, SNNPS State, Ethiopia, PO Box 667.
}

International Journal of Biological and Pharmaceutical Sciences Archive, 2021, 02(01), 135-150

Publication history: Received on 01 July 2021; revised on 25 August 2021; accepted on 27 August 2021

Article DOI: https://doi.org/10.53771/ijbpsa.2021.2.1.0066

\begin{abstract}
Cellulases are a group of hydrolytic enzymes capable of hydrolyzing the most abundant organic polymer that means cellulose to smaller sugar components including glucose subunits. The aim of this study was to screen cellulase producing oyster mushroom collected from Eucalyptus tree bark to evaluate the in vitro production of cellulase by Pleurotus ostreatus using different lignocellulosic substrates, and to characterize the cellulase produced with respect to changes in $\mathrm{pH}$, temperature, and concentration of substrates. A total of ten mushroom specimens were randomly collected from Eucalyptus tree bark in the premise of Holetta Agricultural Research Center campus. All of the collected mushroom specimens were identified morphologically and biochemically as Pleurotus ostreatus and also screened for their ability to produce cellulase by detecting and measuring zone of hydrolysis on commercial media containing Carbxymethyl Cellulose (CMC) as the sole carbon source. These mushroom specimens were cultivated using both solid state fermentation and submerged fermentation systems supplemented with different lignocellulosic substrates (wheat straw, teff straw, bean straw, wood fiber and Eucalyptus tree bark) to identify the most suitable medium for the production of cellulase. The highest enzyme production was obtained on bean straw and wheat straw which resulted in $0.191 \mathrm{U} / \mathrm{ml}, 0.868 \mathrm{U} / \mathrm{ml}$ and $0.389 \mathrm{U} / \mathrm{ml}$; and $0.216 \mathrm{U} / \mathrm{ml}, 0.444 \mathrm{U} / \mathrm{ml}$, and $0.245 \mathrm{U} / \mathrm{ml}$ of FPase, CMCase, and $\beta$ glucosidase in solid state fermentation. The lowest values were, however, obtained in media containing wood fiber in both solid state fermentation and submerged fermentation. Comparison of the lignocellulosic substrates revealed that wheat straw was selected for further growth parameter optimization. The production of cellulase was higher at the $5^{\text {th }}$ day of incubation period, and the optimum $\mathrm{pH}$ and incubation temperature required for maximum cellulase production were 4 and $30^{\circ} \mathrm{C}$, respectively. Sucrose and Yeast extract at $1 \%$ concentration were found to be the most preferred carbon and nitrogen sources for cellulase production by Pleurotus ostreatus. The optimum pH and temperature for cell_free cellulase activity on were found to be 4 and $50^{\circ} \mathrm{C}$, respectively. Generally the cellulases produced by Pleurotus ostreatus were stable and active at temperatures ranging from $20-50^{\circ} \mathrm{C}$. These characteristics hopefully would make this enzyme potentially attractive in a variety of industrial applications including animal feed treatments. There was a linear relationship between cellulase and its substrate concentration for there was an increase in activity with increase in substrate concentration. The relationship between rate of reaction and substrate concentration depended on the affinity of the enzyme for its substrate. Finally the cellulase was tested for its ability to saccharify agricultural wastes and the results showed the highest release of sugars from wheat straw.
\end{abstract}

Keywords: Cellulose; Pleurotus ostreatus; Saccharification; Solid state fermentation; Wheat straw

\footnotetext{
* Corresponding author: Temam Gemeda Genemo; Email: temam2g@gmail.com

Department of Biotechnology, Wachemo university, Hossana, SNNPS State, Ethiopia, PO Box 667. 


\section{Introduction}

Cellulases were initially investigated several decades back for the bioconversion of biomass which helps in the industrial application of enzymes in animal feed, food, textiles, detergents and in paper production [1]. It is the most prominent group of hydrolytic enzymes that catalyze the hydrolysis of $\beta-1,4$ linkages present in cellulose to give glucose. This hexose is fed into the central metabolic pathways of various microorganisms to produce various bio-products. Cellulases are primarily produced in nature by plants, fungi, bacteria, and even some protozoa, mollusks, and nematodes [36]. Large numbers of microorganisms are capable of degrading cellulose. However, only a few of these produce significant quantities of cell free enzyme capable of completely hydrolyzing crystalline cellulose [2]. For the production of industrially important enzymes and bioactive secondary metabolites, fungi isolated from tree barks are known to be potential candidates. These enzymes are mostly ligno-cellulolytic in natures which are used to obtain their energy sources [35]. Major constrains in enzymatic hydrolysis of cellulosic materials for the production of fermentation sugar are low productivity and the cost of cellulases [3].

The most abundant renewable carbon source is the cellulosic material. An agricultural waste is a cheap source of cellulose that can be used for the production of different useful products all over the world [2]. Cellulase production from agricultural wastes is economical as compared to production from pure cellulose. The hydrolysis of cellulose can be done by using enzymes to produce glucose, which can be used for the production of ethanol, organic acids and other chemicals [4]. Production of cellulases by fungal isolates requires optimal conditions for their growth which leads to the release of extracellular enzymes. The growth conditions as well as extracellular enzyme production conditions is likely to vary among isolates. The major components of production medium like carbon and nitrogen sources and physical parameters like temperature, $\mathrm{pH}$ and incubation time were found to be critically affecting the cellulase production and hence need to be optimized for every isolate [27]. Solid state fermentation (SSF) for the production of cellulase is rapidly gaining interest as a cost effective technology for the production of enzyme and higher yield of cellulase is produced under SSF compared to submerged fermentation (SmF) [29].

SSF has many returns over other fermentation processes in a sense that the culture media are simpler and nutrients present in the substrate support growth due to the natural metabolism of the microorganism can secrete enzymes while growing in the solid substrate. It can be of special interest in those processes where the crude fermented product may be used directly as the enzyme source [33]. Cellulase produced by fungus under SSF has advantages for different industrial purposes, namely, in food and fermentation industries, microbial enzymes have attained significant role in biotransformation involving organic solvent media, mainly for bioactive compounds. Cellulolytic enzymes are produced by a number of microorganisms. Fungi and bacteria are the main agents of natural cellulose degradation in the environment. Fungi however are known to secrete cellulases in large amounts [16].

The mushrooms of the genus Pleurotus rank second in the world mushroom market and are the most popular mushroom. The Pleurotus of the class basidiomycetes belongs to a group known as white rot fungi [34] as they produce a white mycelium and are generally cultivated on non-composted lignocellulosic substrates in which various kinds of Pleurotus are commercially cultivated and have considerable economic values. The white rot fungi, Pleurotus species are commonly known as oyster mushrooms. Most of the known species of the genus Pleurotus are edible. One of the most important aspects of Pleurotus species is related to the use of their lignocellulolytic system for a variety of applications.

These includes, bioconversion of lignocellulosic wastes into valuable products, for animal feed and other food products and the use of their ligninolytic enzymes for the biodegradation of organopollutants, xenobiotic and industrial contaminants [30]. P. ostreatus which is well-known among cultivated oyster mushroom species are characterized by its white to lilac-gray spore print and in their natural growing environment, easily recognized by way it grows on the wood in aggregate. Cellulase production by fungi is influenced by culture conditions such as nature and concentration of carbon and nitrogen sources, media composition, $\mathrm{pH}$, temperature, and presence of inducers. This study is initiated in order to produce, characterize, and evaluate for effective cellulase produced by P. ostreatus from the environment and thus contribute to different industries utilizing in their processes. More novel cellulases are needed in the bio-based and bioenergy industry, this study therefore is intended to characterize and evaluate cellulases from Pleurotus ostreatus. This will provide possibility for locally developed combinations of cellulases that can be used in the production of bioethanol. 


\section{Material and methods}

\subsection{Description of the study area}

The study was conducted at Holetta Agricultural Research Center, National Biotechnological Research Laboratory which is located at $28 \mathrm{~km}$ west of Addis Ababa in the Oromia Special Zone Surrounding Finfinne, Oromia Region. Geographically, HARC is located at latitude, longitude, and an altitude of 9³' N, 38 30' E and 2391 meters above sea level, respectively. Typically it has a bimodal rainfall pattern with a mean annual precipitation of about $1100 \mathrm{~mm}$. The main rainy season extends from June to September while the short rainy season from February to April. Mean annual maximum and minimum temperatures are $21^{\circ} \mathrm{C}$ (ranging from $20^{\circ} \mathrm{C}$ and $27^{\circ} \mathrm{C}$ ) and $6^{\circ} \mathrm{C}\left(\right.$ ranging from $2^{\circ} \mathrm{C}$ and $9^{\circ} \mathrm{C}$ ), respectively [32].

\subsection{Oyster Mushroom Collection and Identification}

Fruiting bodies of Pleurotus ostreatus were collected from the bark of live old Eucalyptus tree around Holetta Agriculture Research Center (HARC) by using sterile forceps and handled in sterile polythene bags. The fungi were collected based on their morphology following the methods of Pleurotus species identification guideline given by the Consensus Document on the Biology of Pleurotus species [24]. The major morphological traits considered during fruiting body collection were; occurrence, stem or stipe, odor, shape, and color of the fruiting body.

The fungi grow in shelf-like clusters, nearly absent stem, smooth and thick flesh the whitish kidney-shaped cap having anise odor were considered. The fungi having the above mentioned features were collected from 10 (ten) different trees in early September 2017 and were immediately kept in a freezer at $-20^{\circ} \mathrm{C}$ until cultured on potato dextrose agar (PDA) media. One week later PDA media were prepared and the mushrooms were inoculated on it under aseptic condition following standard microbiological procedures: first the fruiting bodies (gills of the fungi) were cut into pieces of nearly $3 \mathrm{~mm}$ size and subjected to surface sterilization by dipping successively in sterile distilled water, 70\% ethanol, and $5 \%$ $\mathrm{NaOCl}$, each for 4 minutes and finally repeatedly washed with sterile distilled water.

Then after the pieces were kept on sterile filter paper for a few minutes for drying and then placed on prepared PDA plates. All plates were incubated at $28^{\circ} \mathrm{C}$ and daily observation was made. After a week, sub-culturing was done by taking fungal mycelia from incubated plates and transferred to new PDA plates to get purer cultures. The major microscopic features considered during sub-culturing were spore print and colony morphology. The fungi having smooth white to lilac-grey spore with cylindrical to long elliptical shaped morphology were considered as Pleurotus ostreatus [24]. After pure P. ostreatus cultures were obtained, they were maintained on agar slants by sub-culturing every month and preserved at $4^{\circ} \mathrm{C}$ in a refrigerator according to [21].

\subsection{Screening of Cellulase Producing P. ostreatus}

Carboxymethylcellulose containing cellulose as the sole carbon source was inoculated with P. ostreatus. The plates were incubated for 4 days at $30^{\circ} \mathrm{C}$ and positive cellulolytic activity was detected by the formation of clear zones of hydrolysis on a plate after flood the plates with $0.1 \%$ aqueous Congo red followed by repeated washing with $1 \mathrm{M} \mathrm{NaCl}$. The composition of the CMC plate agar medium was (g/l): urea 0.3; ammonium sulphate $1.4 \mathrm{~K} 2 \mathrm{HPO} 41, \mathrm{Fe} 2 \mathrm{SO} 40.3$, CaCl 0.3, Yeast Extract agar 0.25, Peptone 0.75, and CMC 10, The final pH of the medium was adjusted to 5.5 prior to sterilization [31].

\subsection{Source and Preparation of Growth Substrates}

The growth substrates like Teff straw, wheat straw, bean straw, Eucalyptus tree bark and wood fiber were obtained from HARC. The selection of substrate for enzyme production in SSF processes depends upon several factors related with cost and availability of the substrates, and thus may involve screening of several agro-industrial residues. The lignocelluloses substrates were oven dried and ground using a manual grinder. All the resulting powder could pass through a $1 \mathrm{~mm}$ size mesh, and then the powder passed through $1 \mathrm{~mm}$ size mesh used for submerged fermentation and substrate above $1 \mathrm{~mm}$ used for solid-state fermentation.

\subsection{Preparation of Media for Enzyme Production}

\subsubsection{Media for submerged fermentation}

Media used for submerged fermentation were arranged in four separate Erlenmeyer flasks of 250ml capacity containing each $10 \mathrm{~g}$ of a single type of lignocellulosic substrate (Eucalyptus tree, wood fiber, Teff straw, wheat straw and bean straw smaller than $1 \mathrm{~mm})$. Experiments were performed in triplicate at room temperature $\left(25 \pm 2{ }^{\circ} \mathrm{C}\right)$ with shaking at 
$120 \mathrm{rpm}$. The respective substrates were submerged in $200 \mathrm{ml}$ basal medium consisting of (g/l): $(\mathrm{NH} 4)_{2} \mathrm{SO} 4,1.4$; KH2PO4, 2; CaCl2, 0.3; MgSO4, 0.3; FeSO4.7H2O, 0.5; MnSO4.7H2O, 0.16; ZnSO4.7H2O, 0.14; CoCl2, 0.2; and Tween 80, $1 \mathrm{ml}$; with a final $\mathrm{pH}$ of 5.5. The initial $\mathrm{pH}$ of the medium was adjusted to 4.0 prior to sterilization by adding $1 \mathrm{~N} \mathrm{HCl}$. The media was autoclaved at $121^{\circ} \mathrm{C}$ for $20 \mathrm{~min}$ and cooled at room temperature [26].

\subsubsection{Media for solid state fermentation}

Media used for solid-state fermentation were arranged in four separate flasks of $250 \mathrm{ml}$ capacity containing each $10 \mathrm{~g}$ of a single type of lignocellulosic substrate Bean straw, Eucalyptus tree bark, Teff straw, wood fiber and Wheat straw. Then $30 \mathrm{ml}$ of distilled water was added to all bottles following [7]. Experiments were performed in triplicate using Erlenmeyer flasks at $30^{\circ} \mathrm{C}$. Then, the glass bottles were wrapped and autoclaved at $121^{\circ} \mathrm{C}$ for 20 minutes.

\subsection{Preparation of Inoculum}

PDA inoculum was prepared and the fungal stock was stored at $4^{\circ} \mathrm{C}$.then transferred on to PDA plates with a sterilized needle and allowed to grow at $30^{\circ} \mathrm{C}$ for 7 days. The growing edges of the spore were cut with a sterilized $4 \mathrm{~mm}$ core borer and used as inoculum. The inoculum piece was placed inverted down so that they had good contact with the agar surface [11].

\subsection{Growth of P. ostreatus and Extraction of cellulase}

\subsubsection{Submerged fermentation}

Three $\mathrm{mm}^{2}$ of spore-containing PDA was used to inoculate the flasks containing submerged media. After 7 days of mushroom cultivation, biomass was filtered through cotton gauze and the solids separated by centrifugation $10000 \mathrm{rpm}$ for $10 \mathrm{~min}$ at $4^{\circ} \mathrm{C}$. The supernatant was filtered through Whatman no. 1 filter paper and the clear filtrate was used as crude enzyme extract.

\subsubsection{Solid state fermentation}

The solid-state media were inoculated with three mm square of spore-containing PDA. After mixing, the flasks were incubated at $28 \pm 2^{\circ} \mathrm{C}$ temperatures for 7 days under static conditions. After incubation, $100 \mathrm{ml}$ citrate buffer $(0.05 \mathrm{M}$ at pH 5.3) was added and rotated on the rotary shaker at $120 \mathrm{rpm}$ for at least $2 \mathrm{hr}$ at room temperature for maximum enzyme extraction. The liquid homogenate was then filtered through cotton gauze and centrifuged at 10000rpm for 10 minutes at $4^{\circ} \mathrm{C}$ to remove solid particulate matter and the supernatant was filtered through Whatman no. 1 filter paper and the clear filtrate was used as crude cellulase.

\subsection{Enzyme assay}

\subsubsection{Filter paper activity (FPase) assay}

Filter paper degrading activity of cellulase (FPase) is a measure of total cellulolytic activity resulting from different enzyme components present in the culture filtrate. Whatman filter paper strip with $50 \mathrm{mg}$ weight was suspended in 1 $\mathrm{ml}$ of $0.05 \mathrm{M}$ sodium citrate buffer $\mathrm{pH} 4.8$ at $50^{\circ} \mathrm{C}$ in a water bath. Suitable aliquots of enzyme source were added to the above mixture and incubated for 60 minutes at $50^{\circ} \mathrm{C}$. Enzyme blank or without enzyme were run simultaneously in the same manner as specified above. After incubation, 3, 5-dinitrosalicyclic acid (DNS) was mixed. All samples, enzyme blanks, and glucose standards were vigorously boiled for exactly 5 minutes in a water bath after cooled measured at $540 \mathrm{~nm}$ Spectrophotometer. The activity of cellulase was expressed in filter paper units. One unit of filter paper unit (FPU) was defined as the amount of enzyme releasing one $\mu$ mole of reducing sugar from filter paper per minute [8].

\subsubsection{Endoglucanase activity (CMCase) assay}

The reaction mixture contains $1.0 \mathrm{ml}$ of $1 \%$ carboxymethylcellulose (CMC) in $0.2 \mathrm{M}$ acetate buffer $\mathrm{pH}$ 5.0. These reaction mixtures were pre-incubated at $50^{\circ} \mathrm{C}$ in a water bath for 20 minutes. Crude cellulase was added to the reaction mixture and incubated at $50^{\circ} \mathrm{C}$ in a water bath for 60 minutes. Appropriate controls devoid of substrate or enzyme were simultaneously run. The reducing sugar produces in the reaction mixture was determined by dinitrosalicyclic acid method. The reagent 3,5-dinitrosalicyclic acid reagent was added to aliquots of the reaction mixture and the color developed was read at wavelength $540 \mathrm{~nm}$ in a spectrophotometer. One unit of endoglucanase activity was defined as the amount of enzyme releasing one $\mu$ mole of reducing sugar per minute. 


\subsection{3. $\beta$-D-glucosidase activity}

$\beta$-D-glucosidase activity in the culture filtrate was determined according to the method of $\beta$-D-glucosidase activity measured in assay mixture containing $0.2 \mathrm{ml}$ of $5 \mathrm{mM} p$-nitro phenyl $\beta$-D-glucopyranoside dissolved in $0.05 \mathrm{M}$ citrate buffer $\mathrm{pH} 4.8$ and $0.2 \mathrm{ml}$ of dilute enzyme solution with appropriate controls. After incubation for $30 \mathrm{~min}$ at $50^{\circ} \mathrm{C}$, the reaction was stopped by adding $4 \mathrm{ml}$ of $0.05 \mathrm{M} \mathrm{NaOH}$-glycine buffer $\mathrm{pH}$ 10.6. The yellow color $p$-nitrophenol liberated was determined using Spectrophotometer at $405 \mathrm{~nm}$. $\beta$ - D-glucosidase activity was defined as the amount of enzyme liberating one $\mu$ mole of $p$-nitrophenol per minute under standard assay conditions.

\subsection{Fungal Cellulase Production}

\subsubsection{Cellulase production}

Cellulase production was carried out in $250 \mathrm{ml}$ Erlenmeyer flasks each containing Mandels medium $\mathrm{pH} 4.2$ that comprises of $\mathrm{Na}_{2} \mathrm{HPO}_{4} 15 \mathrm{~g}, \mathrm{CaCl}_{2} 0.8 \mathrm{~g}, \mathrm{MgSO}_{4} .7 \mathrm{H}_{2} \mathrm{O} 1.2 \mathrm{~g}, \mathrm{MnSO}_{4} .7 \mathrm{H}_{2} \mathrm{O} 0.0016 \mathrm{~g}, \mathrm{FeSO}_{4} 0.00271 \mathrm{~g}, \mathrm{ZnSO}_{4} 0.0014 \mathrm{~g}$, Urea $3 \mathrm{~g}$, Peptone $0.75 \mathrm{~g}$, Yeast extract $0.3 \mathrm{~g}$ and CMC $10 \mathrm{~g}$ in $200 \mathrm{ml}$ media. To each flask 5 disc spores were added and incubated at $30^{\circ} \mathrm{C}$, with shaking at $130 \mathrm{rpm}$ and samples were collected every $24 \mathrm{hrs}$ until maximum cellulase activity was reached. The culture was centrifuged at $3500 \mathrm{rpm}$ for 10 minutes using a centrifuge and the supernatant was stored at $-20^{\circ} \mathrm{C}$ until required for cellulase assay.

\subsection{Assay for Cellulase Activity}

\subsubsection{Dinitrosalicylic acid assay method for cellulase activity}

Cellulase activity was measured using the 3,5-dinitrosalicylic acid (DNS) method (Miller, 1960), through the determination of an amount of reducing sugars liberated from $1 \%$ carboxymethylcellulose (CMC) solubilized in $50 \mathrm{mM}$ citrate buffer pH 5.0. A combination of $100 \mu$ l enzymes and $900 \mu \mathrm{l}$ of $1 \% \mathrm{CMC}$ substrate solution were incubated at $50^{\circ} \mathrm{C}$ for $5 \mathrm{~min}$. The reaction was stopped by addition of DNS solution and reaction mixture was boiled for $15 \mathrm{~min}$, cooled in water for color stabilization, and the optical density was measured at $540 \mathrm{~nm}$. Cellulase activity was determined by using a calibration curve obtained from standard solutions of glucose. One unit of enzyme activity was defined as the amount of enzyme that released $1 \mu \mathrm{mol}$ of glucose per minute.

\subsection{Characterization of cellulase produced by $P$. ostreatus}

\subsubsection{Effect of $p H$ on cellulase activity}

The optimum $\mathrm{pH}$, of cultures was determined by cultivating in a $250 \mathrm{ml}$ flask containing $50 \mathrm{ml}$ medium with different $\mathrm{pH}$ ranges from 4 to 8 . The $\mathrm{pH}$ of the medium was adjusted by using $1 \mathrm{~N} \mathrm{HCl}$ or $1 \mathrm{~N} \mathrm{NaOH}$. The flasks were incubated at $28^{\circ} \mathrm{C}$ for 5 days and centrifuged at 10,000 rpm for $10 \mathrm{~min}$. Pellet was discarded and supernatant for assay of cellulase.

\subsubsection{Effect of temperature on enzyme activity}

The optimum temperature of the enzyme for hydrolysis of Carboxymethylcellulose (CMC) in $50 \mathrm{mM}$ Citrate buffer $\mathrm{pH}$ 5.0 by P. ostreatus was determined by incubating the mixture of the enzyme $100 \mu \mathrm{l}$ and $1 \% \mathrm{CMC} 900 \mu \mathrm{l}$ for $15 \mathrm{~min}$ at different temperatures ranging from 40 to $80^{\circ} \mathrm{C}$. The reaction was stopped by the addition of DNS solution and cellulase activity was determined.

\subsubsection{Effect of $\mathrm{pH}$ on enzyme activity and stability}

The optimum $\mathrm{pH}$ for cellulase activity was determined by incubating the mixture of the enzyme $100 \mu$ l and $1 \%$ CMC $900 \mu \mathrm{l}$ in the presence of appropriate buffers; $50 \mathrm{mM}$ citrate buffer $\mathrm{pH} \mathrm{3,4,5}$ and 6, 50mM sodium phosphate $\mathrm{pH} 6,7$ and $8,50 \mathrm{mM}$ Tris- $\mathrm{HCl} \mathrm{pH} 8$ and 9 and $50 \mathrm{mM}$ glycine- $\mathrm{NaOH} \mathrm{pH} \mathrm{9,10} \mathrm{and} 11$. The reaction mixtures in various pH buffers were incubated for $5 \mathrm{~min}$ at $50^{\circ} \mathrm{C}$ after which the cellulase activity was assayed by the DNS method.

\subsection{Optimization of culture conditions for cellulase production}

\subsubsection{Effect of pH on cellulase production}

After preparation of the basal liquid medium containing cellulose, suitable aliquots were adjusted at pH 3, 4, 5, and 6 using $0.1 \mathrm{M} \mathrm{NaOH}$ and $0.1 \mathrm{~N} \mathrm{HCl}$ buffer system. After 4 days of incubation at $30^{\circ} \mathrm{C}$, the amount of cellulase was assayed by DNS method. 


\subsubsection{Effects of temperature on cellulase production:}

The effect of temperature was evaluated by inoculating the flasks containing $50 \mathrm{ml}$ of sterile production medium, with $100 \mu \mathrm{l}$ culture. The inoculated flasks were incubated at a different temperature varying from $20^{\circ} \mathrm{C}, 25^{\circ} \mathrm{C}, 30^{\circ} \mathrm{C}, 35^{\circ} \mathrm{C}$ for 5 days and centrifuged at $10,000 \mathrm{rpm}$ for $10 \mathrm{~min}$. Pellet was discarded and supernatant for assay of cellulase.

\subsubsection{Effect of carbon sources on cellulase enzyme production:}

The effect of carbon sources on enzyme production was studied at different concentration $0.5 \%, 1.0 \%, 2.0 \%$ and $2.5 \%$ $(\mathrm{w} / \mathrm{v})$. Fifty $\mathrm{ml}$ of production medium was distributed into the flasks and supplement with different concentration of carbon compounds Glucose, Sucrose, and Lactose. The mixture incubated without carbon source served as a control. The flask was then inoculated with $100 \mu \mathrm{l}$ culture and incubated in an incubator at $28^{\circ} \mathrm{C}$ for 7 days and centrifuged at $10,000 \mathrm{rpm}$ for $10 \mathrm{~min}$. The optimum carbon sources were found by analyzing the result of cellulase production.

\subsubsection{Effect of nitrogen sources on Cellulase enzyme production}

The effect of nitrogen sources on enzyme production was studied at different concentration $0.5 \%, 1.0 \%, 2.0 \%$ and $2.5 \%$ $(\mathrm{w} / \mathrm{v})$. Fifty $\mathrm{ml}$ of production medium was distributed into flasks and supplement with different concentration of nitrogen compounds Ammonium sulfate, beef extract and yeast extract. The flasks were inoculated with $100 \mu \mathrm{l}$ culture and incubated in incubator shake at $28^{\circ} \mathrm{C}$ for 7 days at $130 \mathrm{rpm}$ and centrifuged at $10,000 \mathrm{rpm}$ for $10 \mathrm{~min}$. The mixture incubated without nitrogen source served as a control. The optimum nitrogen sources were found by analyzing the result of cellulase production.

\subsubsection{Effect of substrate concentration on Cellulase activity}

Rate of CMC hydrolysis was determined by incubating $900 \mu$ l substrate (CMC) at various concentrations $(0.1 \%, 0.5 \%$, $1 \%, 1.5 \%, 2 \%, 2.5 \%$ and $3 \%$ ) with $100 \mu \mathrm{l}$ of crude cellulase. The enzymes incubated without CMC served as a control for 10 minutes. The effects of substrate concentration were assayed by DNS method.

\subsection{Saccharification of substrates by cellulase}

Agro-waste was ground into powder using a grinder. $10 \mathrm{~g} / \mathrm{l}$ of the substrate was suspended in $50 \mathrm{mM}$ acetate buffer $\mathrm{chH}$ 5) and autoclaved at $121^{\circ} \mathrm{C}$ for $15 \mathrm{~min}$ and $15 \mathrm{ml}$ of substrate suspension taken into $100 \mathrm{ml}$ of Erlenmeyer flasks and the substrate was added into $5 \mathrm{ml}$ of culture filtrate obtain from cellulolytic fungi. Saccharification was performed in a water bath at $27 \pm 2^{\circ} \mathrm{C}$ for $24 \mathrm{hrs}$ and the supernatant was centrifuged at $2500 \mathrm{rpm}$ for $15 \mathrm{~min}$ and total reducing sugar was assayed using the DNS method. The percentage saccharification was calculated as:

$$
\text { Saccharification }(\%)=\frac{\text { Glucose }(\mathrm{mg} / \mathrm{ml})}{\text { substrate }(\mathrm{mg} / \mathrm{ml}} \times 100
$$

\subsection{Data Analysis}

The study was carried out experimentally with three replications and the data was fed into Microsoft Excel and presented on the average of three replicates obtained from there independent experiments. The results were expressed as the mean of data obtained from triplicate experiments \pm SD.

\section{Results and discussion}

\subsection{Identification of P. ostreatus}

Identification of $P$. ostreatus was done at their natural habitat living Eucalyptus tree based on the color difference of their fruiting bodies. This well-known mushroom is easily recognized by the way it grows on the wood in shelf-like clusters, its relatively large size, its whitish gills that run down a stubby, nearly-absent short, stipe, and its whitish to lilac-gray spore print. Only white colored fruiting bodies forming overlapping shelves or clusters on logs were collected as those were the features of $P$. ostreatus. In the laboratory, the fungus was identified based on its colony morphology as well as microscopic visualizations spore print. The organisms producing smooth and white to lilac-gray colored spore print with cylindrical to long-elliptical shape were considered. The microscopic observations showed smooth, cylindrical to narrowly kidney shaped features. These colony characteristics and microscopic visualizations were similar to the genus P. ostreatus (OECD, 2005); hence the isolated fungus was concluded to be P. ostreatus. The fungus was further sub-cultured for cellulase production detection. 


\subsection{Screening of $\boldsymbol{P}$. ostreatus for cellulase production}

Screening of cellulase producing fungi was performed on CMC agar plates flooded with $0.1 \%$ Congo red and washed with $1 \mathrm{M} \mathrm{NaCl}$. Congo red has the ability to bind with cellulose and produce bright red color, if the enzyme acts on the substrate, the cellulose may be used up, so it ends with a zone of decolorization.

Depending on the diameter of the clear zone around the colony, potential fungal isolates were identified as cellulase producing fungi and its initial identification was done by fungal staining and colony morphology. The Pleurotus ostreatus show maximum clearance around the colony (Table 1) [22]. Out of these strains, some isolates showed hydrolyzing zones on agar plates containing CMC as core carbon source, after Congo-red staining the hydrolyzing zone diameter and colony diameter were listed \& given below in Table 1.

Table 1 Clear zone of CMC hydrolysis of different isolates

\begin{tabular}{|c|c|c|c|c|}
\hline $\begin{array}{c}\text { Serial } \\
\text { No }\end{array}$ & $\begin{array}{c}\text { Isolate } \\
\text { No }\end{array}$ & $\begin{array}{c}\text { Colony } \\
\text { Diameter(mm) }\end{array}$ & $\begin{array}{c}\text { Zone } \\
\text { Diameter(mm) }\end{array}$ & $\begin{array}{c}\text { Zoneof } \\
\text { hydrolysis (mm) }\end{array}$ \\
\hline 1 & OM1 & 8.7 & 10 & 1.3 \\
\hline 2 & OM2 & 7.5 & 9 & 1.5 \\
\hline 3 & OM3 & 9.2 & 10 & 0.8 \\
\hline 4 & OM4 & 8.6 & 12 & 3.4 \\
\hline 5 & OM5 & 8.6 & 9.3 & 0.7 \\
\hline 6 & OM6 & 9 & 9 & - \\
\hline 7 & OM7 & 8.8 & 9.5 & 0.7 \\
\hline 8 & OM8 & 8 & 8 & 0.8 \\
\hline 9 & OM9 & 9 & 9.8 & 1 \\
\hline 10 & OM10 & 9.4 & 10.4 & - \\
\hline
\end{tabular}

\subsection{Cellulase Production on Different Lignocellulosic Substrates}

Production of cellulase enzyme by P. ostreatus has grown on different lignocellulosic substrates; bean straw (BS), Eucalyptus bark (EB), Teff straw (TS), wheat straw (WS) and wood fiber (WF) under solid state and submerged fermentation condition was evaluated and the results are summarized and presented in Table 2. Each substrate was served as a sole nutrient source in both media form.

Table 2 Cellulase production (U/ml) by P. ostreatus grown on different lignocellulosic substrates under SSF and SmF

\begin{tabular}{|c|c|l|l|l|l|c|}
\hline & & SSF & & & SMF & \\
\hline Substrate & FPase & CMCase & $\boldsymbol{\beta}$-glucosidase & FPase & CMCase & $\boldsymbol{\beta}$-glucosidase \\
\hline BS & 0.191 & 0.867 & 0.398 & 0.122 & 0.101 & 0.098 \\
\hline EB & 0.104 & 0.258 & 0.208 & 0.124 & 0.217 & 0.158 \\
\hline TS & 0.098 & 0.228 & 0.215 & 0.081 & 0.112 & 0.116 \\
\hline WF & 0.106 & 0.114 & 0.158 & 0.083 & 0.094 & 0.088 \\
\hline WS & 0.216 & 0.444 & 0.245 & 0.117 & 0.14 & 0.115 \\
\hline
\end{tabular}

When different substrates were used in both solid-state and submerged fermentation medium, the highest enzyme production was obtained on bean straw and wheat straw which is, $0.191 \mathrm{U} / \mathrm{ml}, 0.867 \mathrm{U} / \mathrm{ml}$ and $0.389 \mathrm{U} / \mathrm{ml}$, and 0.216 $\mathrm{U} / \mathrm{ml}, 0.444 \mathrm{U} / \mathrm{ml}$, and $0.245 \mathrm{U} / \mathrm{ml}$ of FPase, CMCase and $\beta$-glucosidase in solid-state fermentation and the lowest was obtained in media containing wood fiber, $0.106 \mathrm{U} / \mathrm{ml}, 0.114 \mathrm{U} / \mathrm{ml}$ and $0.158 \mathrm{U} / \mathrm{ml}$, and $0.083 \mathrm{U} / \mathrm{ml}, 0.094 \mathrm{U} / \mathrm{ml}$, and $0.088 \mathrm{U} / \mathrm{ml}$ of FPase, CMCase and $\beta$-glucosidase in solid-state and submerged fermentation, respectively (Table 2). This 
indicated that bean straw and wheat straw are the most suitable substrate for cellulase production by P. ostreatus when compared with other study substrates.

Wheat straw was the second highest in SSF and SmF. The production of cellulase by P.ostreatus was higher in SSF, using different substrates as a carbon source when compared to the results obtained in SmF with the same substrates.

Based on the substrate selection criteria bean straw was not selected for further study in this experiment. Study substrates were analyzed by an economical point of view, its availability around study area and management to use it as substrate. Bean straw is more scare and needs high management because of easily perishable. Wheat straw is an inexpensive, agricultural by-product, which contains a lot of cellulose.

Therefore; further studies were conducted using wheat straw as a carbon source. Eucalyptus tree bark is a natural substrate for the study organism, but the study showed that it results in the lowest production of cellulase. This is due to nutrient content found in it, which the organism highly need protein nutrient to grow (why it is highest in bean straw). The production of cellulase by P. ostreatus was higher in SSF, using different substrates as a carbon source when compared to the results obtained in SmF with the same substrates (Table 2). A higher efficiency on enzymatic production SSF is described by several authors for various enzymes and microorganisms [12].

While in submerged fermentation ( $\mathrm{SmF}$ ), the fungus is exposed to hydrodynamic forces; in SSF growth is restricted to the surface of the solid matrix. Another factor is that the use of solid systems (SSF) provides the fungus with an environment closer to its natural habitat wood and decayed organic matter, which stimulates the fungi to produce more hemicellulolytic enzymes [6]. Since this enzyme has an ability to hydrolyze hemicellulosic substrates and function at a wide range of temperature and $\mathrm{pH}$, it can be a great attraction to be utilized in industry after pretreatment of hemicellulose from agricultural wastes to fermentable sugars.

\subsection{Optimization of culture conditions for cellulase production}

\subsubsection{Effect of incubation period on cellulase production}

The rate of production of cellulase by P. ostreatus in shake flasks (Figure 2) shows the production of cellulase increased with the increase in the incubation period and reached a maximum after the $5^{\text {th }}$ day of incubation. Further increased the incubation period, however, resulted in the gradual decrease in the production of cellulase. Therefore, the incubation period of the $5^{\text {th }}$ day was found to be optimal for cellulase production by $P$. ostreatus. The optimization of the time course is of prime importance for cellulase biosynthesis by fungi [14]. The decrease in the production of cellulase by $P$. ostreatus after the $5^{\text {th }}$ day of the incubation period is due to the depletion of nutrients in the medium which stressed the fungal physiology resulting in the inactivation of secretary machinery of the enzymes [23].

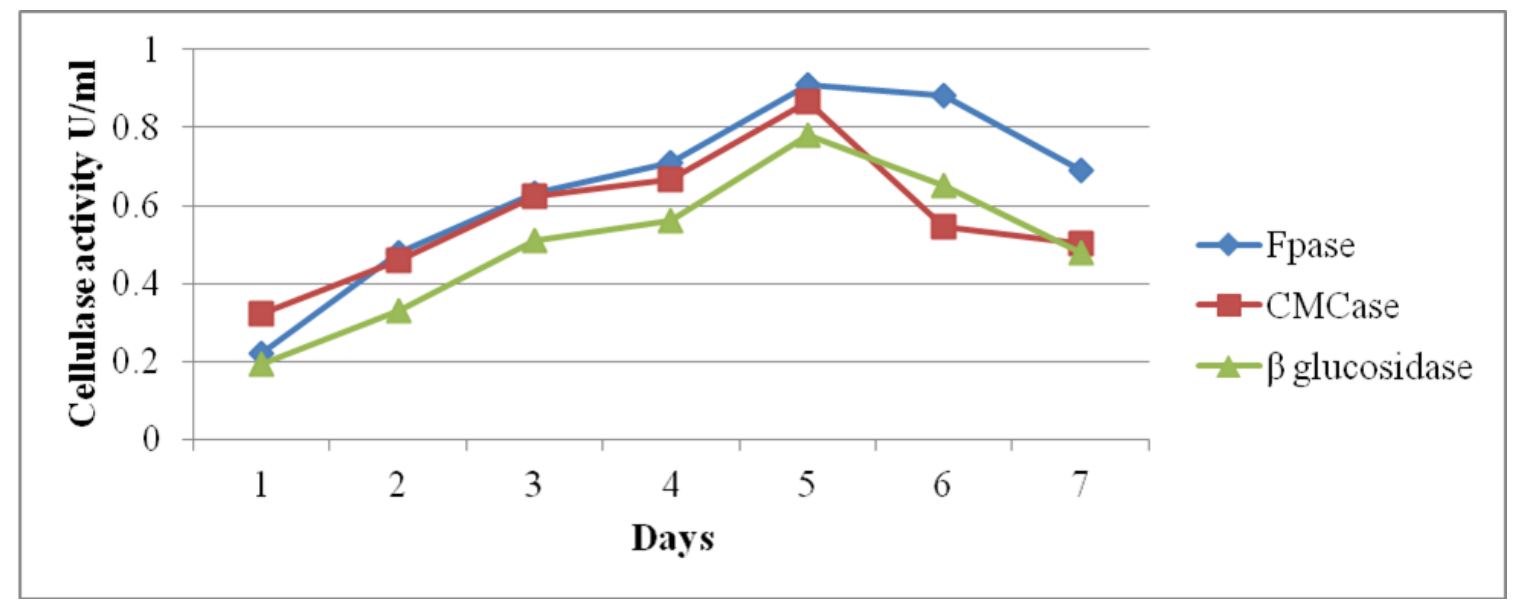

Figure 1 Effect of incubation period on cellulase production

\subsubsection{Effect of pH on enzyme production}

Effect of pH on enzyme production was evaluated at $\mathrm{pH}$ values $3,4,5$ and 6 . Cellulase yield by P. ostreatus appear to depend on $\mathrm{pH}$ value. Result illustrated by (Figure 3) clearly show that cellulase production, expressed as enzyme activity, gradually increased as the $\mathrm{pH}$ value increased from 3 to 4 reached its maximum at $\mathrm{pH}$ of 4 which is $(0.844$ $\mathrm{U} / \mathrm{ml}),(0.72 \mathrm{U} / \mathrm{ml})$ and $(0.621 \mathrm{U} / \mathrm{ml})$ of FPase, CMCase, and $\beta$-glucosidase. The enzyme production was favored in acidic 
range of pH 4 to 6 and result of the present study were considerably similar to the results reported by where Trichoderma reesei was shown to produce maximum cellulase at a $\mathrm{pH}$ of 4 . The effect of $\mathrm{pH}$ on cellulase production by these fungi was found to be in agreement with the findings of [18] who reported that CMCase, Avicelase and FPase activities exhibited an optimum $\mathrm{pH}$ approximately 4 , while the $\mathrm{pH}$ optimum for $\beta$ glucosidase production was between pH 5 and 6.

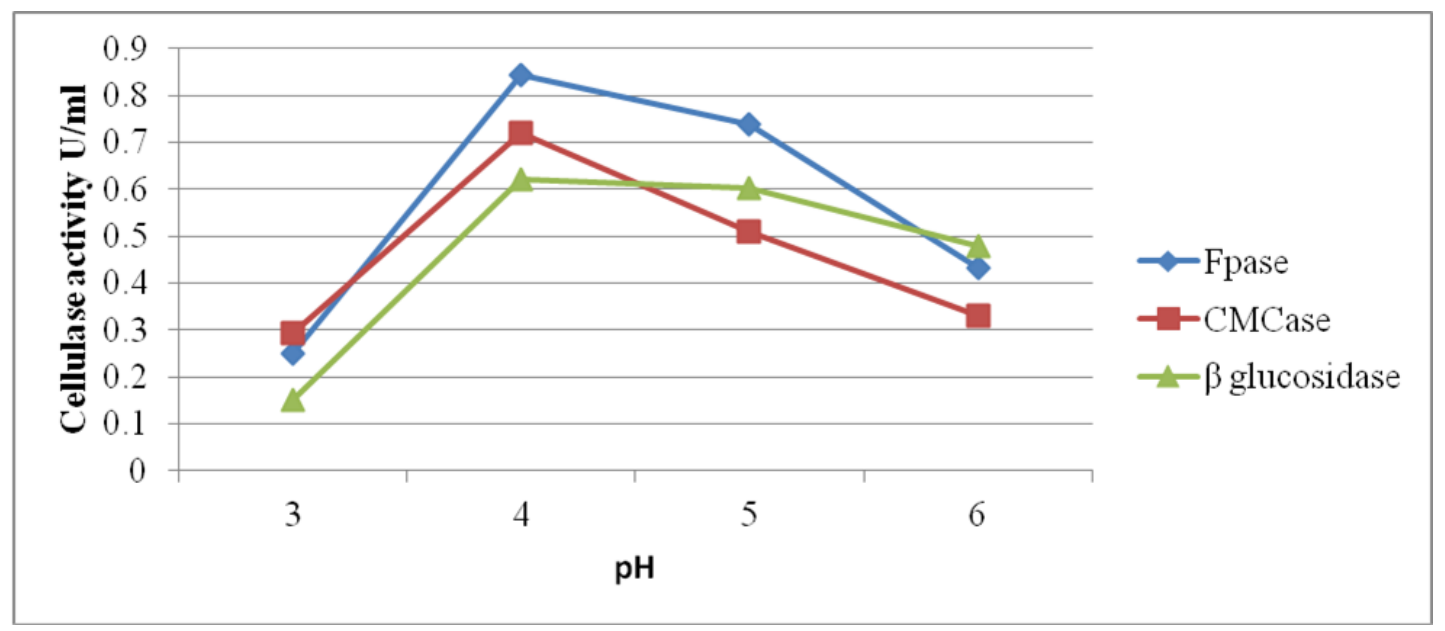

Figure 2 Effect of $\mathrm{pH}$ on cellulase production under SSF

\subsubsection{Effect of temperature on cellulase production}

Incubation temperature plays an important role in the metabolic activities of a microorganism. Even slight changes in temperature can affect enzyme production. Since enzyme is a primary metabolite produced during exponential growth phase, the incubation at high temperature could lead to poor growth and thus a reduction in enzyme yield. The effect of temperature on cellulase activity was determined by incubating the culture at different temperature, i.e. $20^{\circ} \mathrm{C} 25^{\circ} \mathrm{C}, 30^{\circ} \mathrm{C}$ and $35^{\circ} \mathrm{C}$. The results showed that the optimum temperature for the production of cellulase, i.e. FPase $(0.542 \mathrm{U} / \mathrm{ml})$, CMCase $(0.46 \mathrm{U} / \mathrm{ml})$ and $\beta$ glucosidase $(0.38 \mathrm{U} / \mathrm{ml})$ by $P$. ostreatus at $30^{\circ} \mathrm{C}$. This result was, however, different from the findings of [10] who reported that the optimum temperature for cellulase production by A. niger \& A. fumigatus was $40^{\circ} \mathrm{C}$. The optimum temperature for cellulase production depends on the strain variation of the microorganism. The present result is probably different from that of [10] because of differences in the studied fungal species.

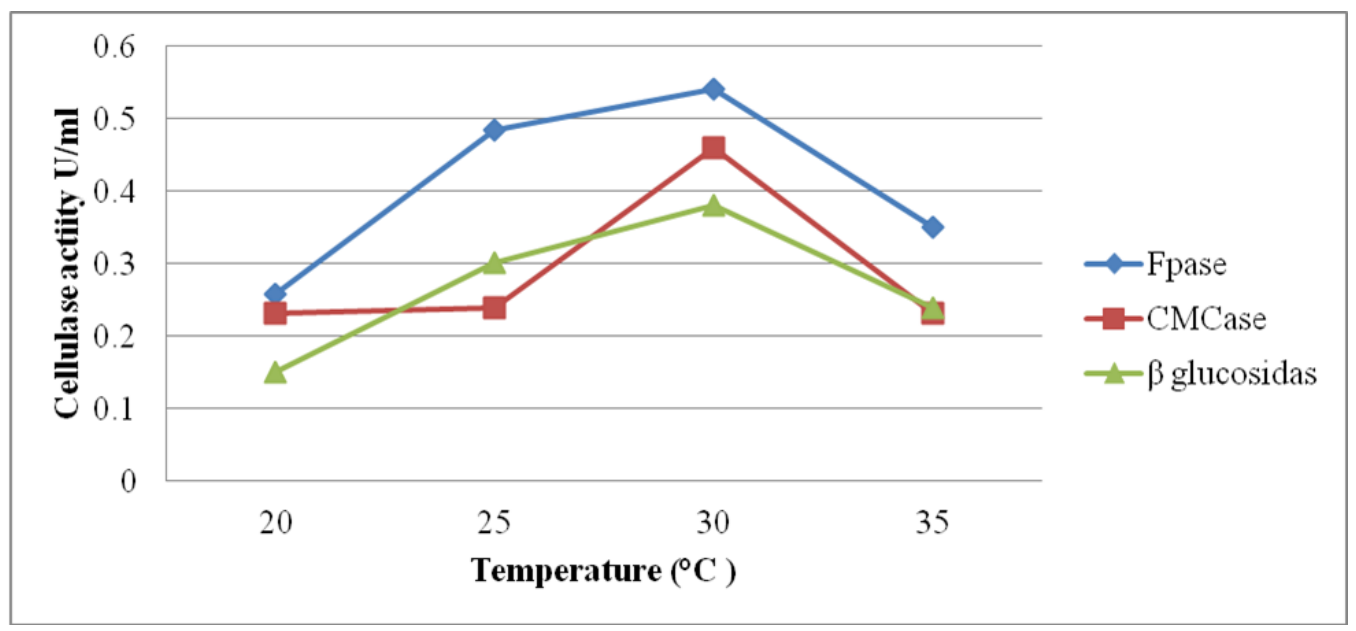

Figure 3 Effect of temperature on cellulase production under SSF

\subsubsection{Effect of carbon source on cellulase production}

The production of cellulase is a key factor in the hydrolysis of cellulosic material and is essential to make the process economically viable. Cellulase production by $P$. ostreatus increased with increase in initial sugar concentration from $0.5 \%$ to $1.0 \%$. Regardless of the type of carbon source utilized, highest cellulase production was obtained at $1 \%$ concentration of sugars tested. With further increase in sugar concentration, reduction in enzyme activity was observed 
when compared with control [20] also reported the maximum yield of cellulase at $1 \%$ concentration with different carbon sources in Trichoderma viride. Sucrose was the most effective carbon source for cellulase production, i.e. for FPase $(2.67 \mathrm{U} / \mathrm{ml})$, CMCase $(2.16 \mathrm{U} / \mathrm{ml})$ and $\beta$-glucosidase $(2.05 \mathrm{U} / \mathrm{ml})$ production followed by glucose and lactose. Same carbon sources have been optimized by different workers for cellulase production [28].

Table 3 Effect of carbon source on cellulase production under SSF ( \pm SE)

\begin{tabular}{|l|c|c|c|c|}
\hline Carbon source & Concentration (\%) & FPase & CMCase & $\boldsymbol{\beta}$ - glucosidase \\
\hline \multirow{4}{*}{ Glucose } & 0 & $0.32 \pm 0.03$ & $0.38 \pm 0.04$ & $0.41 \pm 0.04$ \\
\cline { 2 - 5 } & 0.5 & $0.68 \pm 0.04$ & $0.48 \pm 0.03$ & $0.42 \pm 0.02$ \\
\cline { 2 - 5 } & 1 & $2.32 \pm 0.08$ & $1.92 \pm 0.07$ & $1.90 \pm 0.09$ \\
\cline { 2 - 5 } & 2 & $0.96 \pm 0.05$ & $0.97 \pm 0.04$ & $0.92 \pm 0.05$ \\
\hline \multirow{4}{*}{ Lactose } & 2.5 & $0.63 \pm 0.04$ & $0.73 \pm 0.04$ & $0.54 \pm 0.04$ \\
\cline { 2 - 5 } & 0 & $0.41 \pm 0.03$ & $0.31 \pm 0.04$ & $0.41 \pm 0.05$ \\
\cline { 2 - 5 } & 0.5 & $0.43 \pm 0.05$ & $0.34 \pm 0.04$ & $0.47 \pm 0.05$ \\
\cline { 2 - 5 } & 1 & $1.86 \pm 0.08$ & $1.92 \pm 0.07$ & $1.89 \pm 0.08$ \\
\hline \multirow{3}{*}{ Sucrose } & 2 & $1.27 \pm 0.06$ & $0.86 \pm 0.05$ & $1.62 \pm 0.05$ \\
\cline { 2 - 5 } & 0 & $0.82 \pm 0.05$ & $0.52 \pm 0.04$ & $1.11 \pm 0.04$ \\
\cline { 2 - 5 } & 0.5 & $0.26 \pm 0.02$ & $0.34 \pm 0.03$ & $0.37 \pm 0.03$ \\
\cline { 2 - 5 } & 1 & $0.68 \pm 0.05$ & $0.51 \pm 0.06$ & $0.41 \pm 0.04$ \\
\cline { 2 - 5 } & 2 & $2.67 \pm 0.07$ & $2.16 \pm 0.07$ & $2.05 \pm 0.08$ \\
\hline
\end{tabular}

\subsubsection{Effect of nitrogen source on enzyme production}

Results indicated that the source of nitrogen greatly affected the production of cellulase. The microorganisms which have an important industrial application can utilize inorganic and organic nitrogen sources.

Table 4 Effect of nitrogen source on cellulase production under SSF $( \pm$ SE)

\begin{tabular}{|l|c|l|l|c|}
\hline Nitrogen sources & Concentration (\%) & FPase & CMCase & $\boldsymbol{\beta}$ - glucosidase \\
\hline \multirow{3}{*}{ Yeast Extract } & 0 & $0.24 \pm 0.04$ & $0.19 \pm 0.03$ & $0.15 \pm 0.03$ \\
\cline { 2 - 5 } & 0.5 & $0.32 \pm 0.03$ & $0.31 \pm 0.04$ & $0.31 \pm 0.02$ \\
\cline { 2 - 5 } & 1 & $2.21 \pm 0.07$ & $1.93 \pm 0.07$ & $1.94 \pm 0.05$ \\
\cline { 2 - 5 } & 2 & $1.52 \pm 0.07$ & $0.83 \pm 0.05$ & $0.89 \pm 0.04$ \\
\hline \multirow{4}{*}{ Beef Extract } & 2.5 & $0.92 \pm 0.07$ & $0.63 \pm 0.05$ & $0.44 \pm 0.03$ \\
\cline { 2 - 5 } & 0 & $0.39 \pm 0.05$ & $0.22 \pm 0.03$ & $0.31 \pm 0.03$ \\
\cline { 2 - 5 } & 0.5 & $0.72 \pm 0.05$ & $0.31 \pm 0.04$ & $0.37 \pm 0.03$ \\
\cline { 2 - 5 } & 2 & $2.11 \pm 0.07$ & $1.92 \pm 0.06$ & $1.94 \pm 0.06$ \\
\hline \multirow{3}{*}{$\begin{array}{l}\text { Ammonium } \\
\text { sulfate }\end{array}$} & 2.5 & $1.52 \pm 0.07$ & $0.83 \pm 0.05$ & $0.92 \pm 0.06$ \\
\cline { 2 - 5 } & 0 & $0.92 \pm 0.07$ & $0.63 \pm 0.05$ & $0.46 \pm 0.05$ \\
\cline { 2 - 5 } & 1 & $0.21 \pm 0.03$ & $0.16 \pm 0.06$ & $0.11 \pm 0.03$ \\
\cline { 2 - 5 } & 2 & $0.23 \pm 0.03$ & $0.18 \pm 0.03$ & $0.14 \pm 0.02$ \\
\hline & 2.5 & $1.72 \pm 0.05$ & $1.62 \pm 0.06$ & $1.68 \pm 0.05$ \\
\hline
\end{tabular}


Data revealed that the supplementation of the production medium by organic and inorganic nitrogen sources (i.e. beef extract, yeast extract and ammonium sulfate) ranging in concentrations from 0.5 to $2.5 \%$ stimulated the cellulase yield and activity. Evidently, the data (Table 4) indicated that P. ostreatus exhibited maximum cellulase activity at $1 \%$ concentration of different nitrogen sources. Yeast extract proved to be the best nitrogen source for cellulase production [FPase $(2.21 \mathrm{U} / \mathrm{ml})$, CMCase $(1.93 \mathrm{U} / \mathrm{ml})$ and $\beta$-glucosidase $(1.91 \mathrm{U} / \mathrm{ml})$ ] followed by Beef extract and ammonium sulfate. Amongst different nitrogen sources tested, growth was boosted in the presence of organic nitrogen source when compared to control [37].

\subsection{Characterization of Cellulase}

\subsubsection{Effects of $\mathrm{pH}$ on activity of cellulose}

In order to determine the optimum working $\mathrm{pH}$ for cellulase enzyme, the crude extract was first harvested and incubated at $50^{\circ} \mathrm{C}$ within different $\mathrm{pH}$ range from $4-8$ for 15 minutes. In this study as the $\mathrm{pH}$ value increased, cellulase activity also increased and its highest activity was observed at pH 4 to 5 (Figure 5). The maximum activity for CMCase and $\beta$-glucosidase was observed at $\mathrm{pH} 4$, while for FPase the activity was highest at a $\mathrm{pH}$ of 5 . This supports the findings of [18] who reported that CMCase, Avicelase and FPase activities exhibit a pH optimum of 5 and 6 . The instability of these enzymes at very low or very high $\mathrm{pH}$ values is due to the fact that they are proteins that are generally denatured at extreme $\mathrm{pH}$ values.

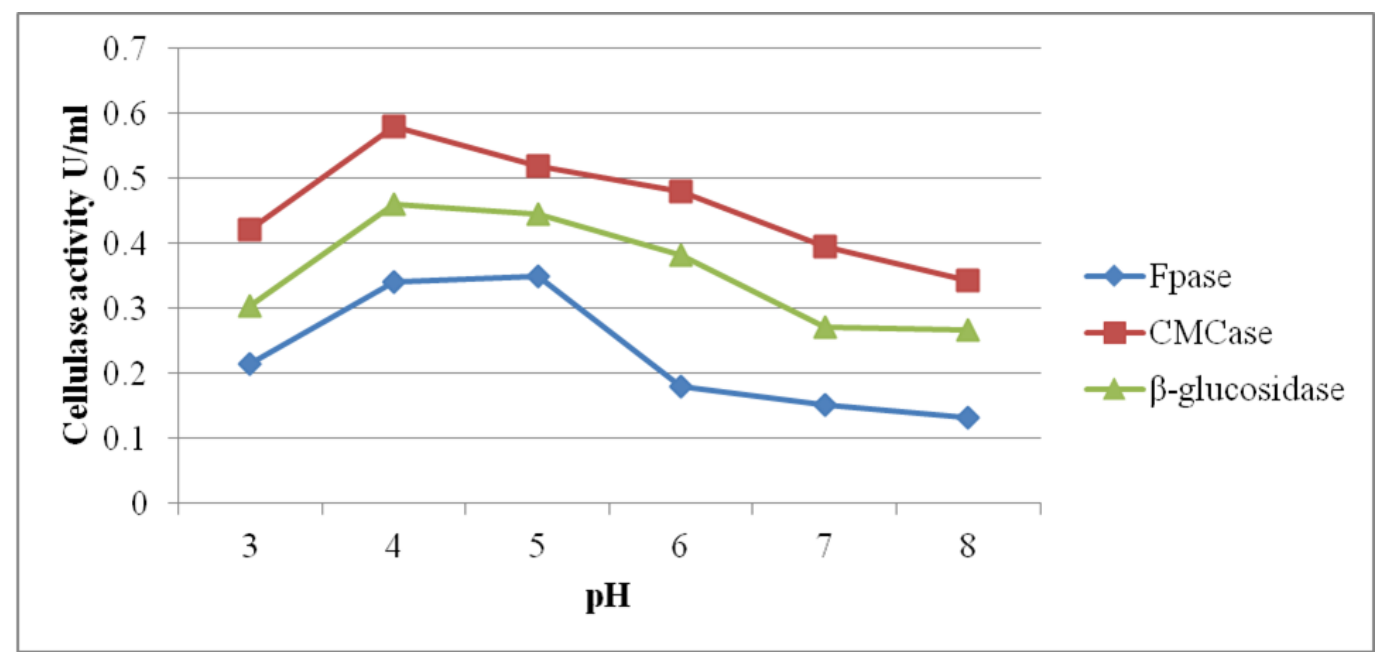

Figure 4 Effect of $\mathrm{pH}$ on cellulase activity

The result is in agreement with that of [1] who indicated that enzyme activity has a bell shaped profile with an optimum $\mathrm{pH}$. The report also showed that the optimum $\mathrm{pH}$ for cellulase activity was 4.0. The dependence of cellulase activity on $\mathrm{pH}$ usually renders a bell-shaped profile.

\subsubsection{Effect of temperature on activity of cellulose}

The optimum temperature for activity of the cellulases was determined at temperatures ranging between 40 and $80^{\circ} \mathrm{C}$. The results showed that as temperature increases cellulase activity also increases up to a certain level of temperature. The highest activity of cellulase (FPase, CMCase, and $\beta$-glucosidase) was observed in the range of $40-60^{\circ} \mathrm{C}$ and the maximum activity was observed at $50^{\circ} \mathrm{C}$. However, a further increase in temperature resulted in a decrease in cellulase activity. The least activity was observed at $80^{\circ} \mathrm{C}$ (Figure 6). Temperatures above $60^{\circ} \mathrm{C}$ generally result in the loss of the moisture content of the substrate which affects metabolic activities, reduces growth and enzyme production by microorganisms. Due to high temperature, the growth of fungal isolates was greatly inhibited and hence, enzyme formation was seriously hampered. 


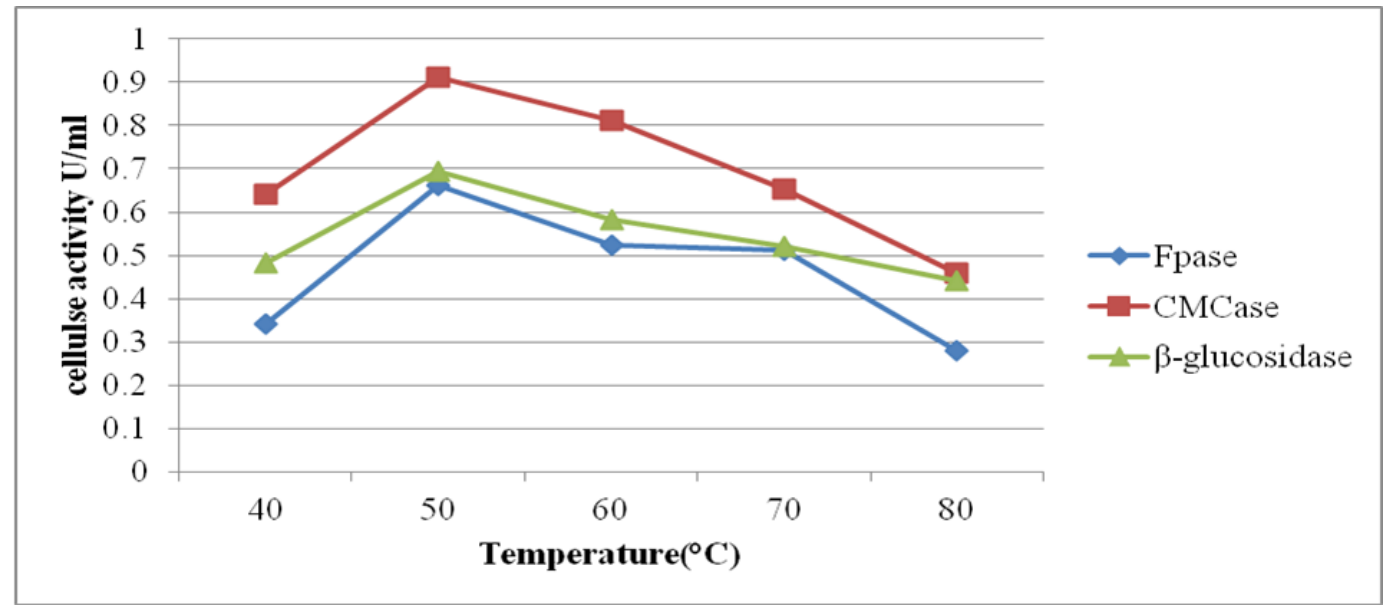

Figure 5 Effect of Temperature $\left({ }^{\circ} \mathrm{C}\right)$ on cellulase activity

\subsubsection{Effect of substrate concentration on cellulase activity}

The increased in the enzyme activity at substrate concentration ranging from $0.1 \%$ to $3 \%$ of the CMC suggests the ability to produce more of the cellulase at an optimal substrate concentration of $2.5 \%$ as shown in (Figure 7). Since the substrates contain different minerals apart from carbon, which may serve as nutrient supplements, an increase in substrate concentration leads to an increase in these nutrients that may adversely affect the cell concentration. The increased in enzyme production until the optimum was obtained due to the availability of cellulose in the medium and decreased in production beyond optimum concentration is as a result of an inhibiting effect of accumulated cellobiose and cellodextrin of low degree of the polymerization of the growth medium [9] further stated that it might also be due to specific binding of the enzyme with substrates.

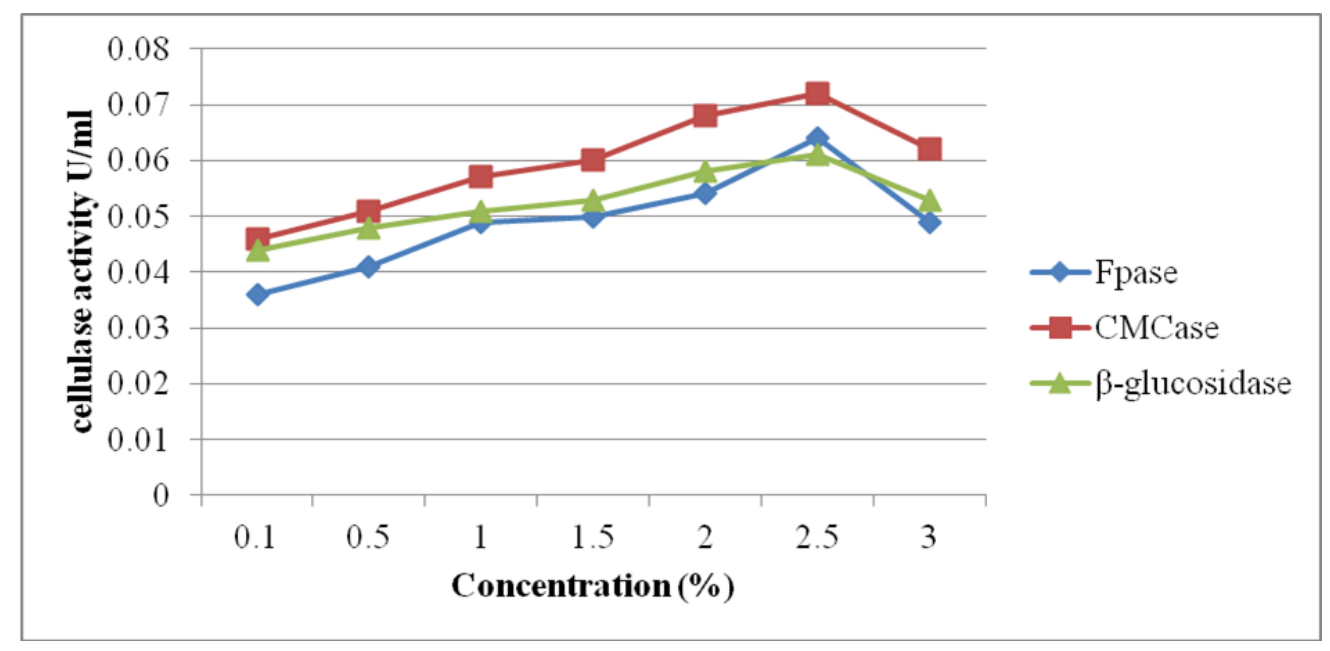

Figure 6 Effect of substrate concentration on cellulase production

\subsection{The extent of saccharification of lignocellulosics by $P$. ostreatus cellulose}

Saccharification of wheat straw, Eucalyptus bark and Teff Straw by the cellulase of P. ostreatus was evaluated. The bioconversion efficiency was assessed via quantification of released monosaccharides in $24 \mathrm{hrs}$. The maximum saccharification by crude cellulase was recorded from wheat straw, followed by Eucalyptus bark and Teff straw when compared with control. 
Table 5 Saccharification of lignocellulosic substrates by $P$. ostreatus cellulose

\begin{tabular}{|l|c|c|c|}
\hline \multicolumn{4}{|c|}{ Saccharification (\%) } \\
\hline \multicolumn{1}{|c|}{ Substrate } & FPase & CMCase & $\boldsymbol{\beta}$-glucosidases \\
\hline Wheat Straw & 17.7 & 20.2 & 18.1 \\
\hline Teff Straw & 13.5 & 14.6 & 13.9 \\
\hline E.Bark & 14.6 & 15.5 & 15.1 \\
\hline Control & 1 & 1.02 & 0.993 \\
\hline
\end{tabular}

The culture supernatant crude enzyme contained the complete cellulose degrading system for hydrolysis of cellulose to glucose produced by the fungus. $\beta$-glucosidases hydrolyze cellobiose to glucose in order to eliminate cellobiose inhibition and it is not only required for more complete hydrolysis of cellulose but also stimulates the overall cellulolytic reaction in a synergistic manner. Cellulase enzyme systems are not merely an agglomeration of enzymes representing the three enzymes, but rather act in a coordinated manner to efficiently hydrolyze cellulose into glucose [19].

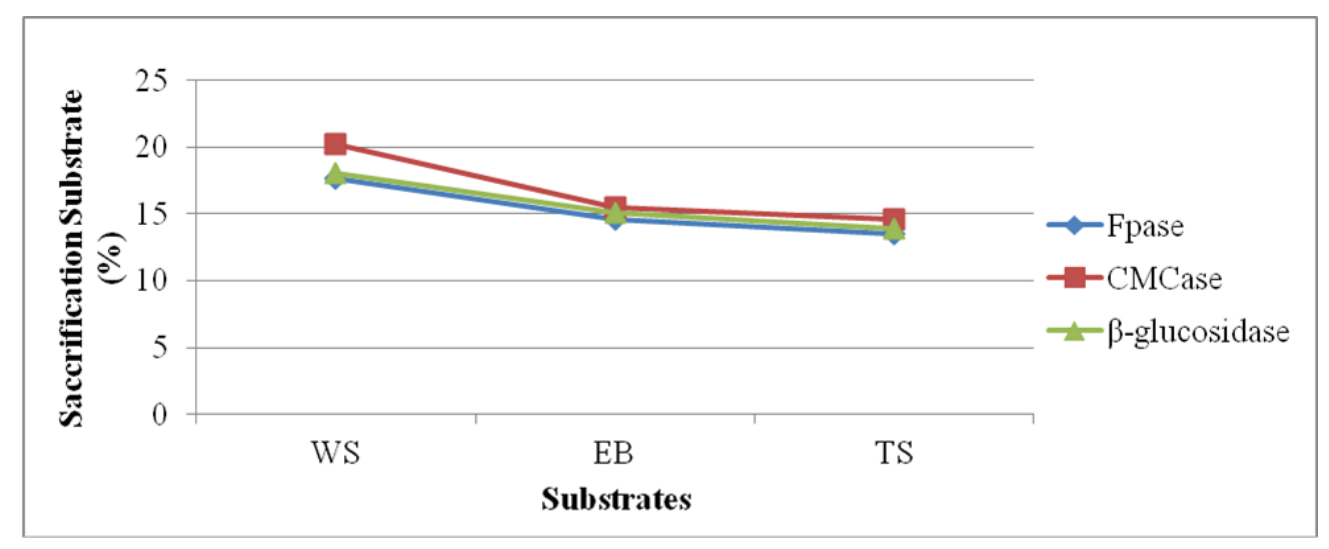

Figure 7 Saccharification of lignocellulosic substrates by cellulase

Enzymatic conversion of cellulose to food, fuel and chemical feedstock is a well-established process. The enzymatic conversion of the carbohydrate part of the lignocellulosic material has received considerable interest during recent years. This source of raw material is available in abundance and generally free of cost. This could be converted into fermentable sugars. To reduce the production cost and enhance the formation of cellulases, which are both essential for the utilization of the carbohydrate components of lignocellulosic, different strategies can be applied. Lignocellulosic waste of wheat straw, teff straw and Eucalyptus bark left over otherwise for natural degradation in the field were effectively used as a component in the medium for the production of enzymes [3].

Subsequently, these enzymes produced on the medium containing wheat agro-waste can be further implicated in the saccharification of the same agro-waste. P. ostreatus synthesized cellulases were used for saccharification of wheat straw, Eucalyptus bark, and teff straw. The cellulolytic enzyme complex when incubated with the agro-waste released sugars. The degree of saccharification was assayed on the basis of the release of the reducing group. The saccharification of wheat straw by an enzyme produced by P. ostreatus indicates the specificity of the enzyme towards the substrates. Enzymes synthesized on wheat straw medium released more glucose. This can be attributed to the other enzymes like ligninase and hemicellulases in the agro-waste medium, synthesized along with cellulases.

\section{Conclusion}

This study was conducted to screen cellulase producing oyster mushroom species collected from Eucalyptus tree bark in Holetta agricultural Research center, to evaluate the in vitro production of cellulase by $P$. ostreatus using different lignocellulosic substrates, and to produce characterize and evaluate the effective degradation of cellulose by cellulase produced from $P$. ostreatus with respect to changes in $\mathrm{pH}$, temperature, and concentration of substrates. A total of 10 mushroom specimens were randomly collected from Eucalyptus tree bark in the premise of Holetta Agricultural 
Research Center campus. The collected mushroom specimens were identified morphologically and biochemically as $P$. ostreatus and also screened for cellulase production depend on the clear zone formation on carboxymethylcellulose containing cellulose as a sole carbon source.

Screened mushroom specimen were cultivated using both solid state and submerged fermentation systems supplemented with different substrates (wheat straw, teff straw, bean straw, wood fiber and Eucalyptus tree bark) to identify the most suitable medium for the production of cellulase. The highest enzyme production was obtained on bean straw and wheat straw in solid-state fermentation and the lowest was obtained in media containing wood fiber in solidstate fermentation and submerged fermentation, respectively. Production of cellulase by study organism was better in SSF system than SMF system and among tested lignocellulosic substrates; Wheat Straw was selected for further growth parameter optimization.

Crude cellulase extract was harvested by sodium acetate buffer ( $\mathrm{pH} 4.8)$ and centrifuged at $10000 \mathrm{rpm}$ at $4^{\circ} \mathrm{C}$ for 10 minutes and later on, the clear supernatant was collected through decantation which was used for cellulase activity determination. The production of cellulase was higher at the $5^{\text {th }}$ day of the incubation period, and the maximal $\mathrm{pH}$ and incubation temperature were 4 and $30^{\circ} \mathrm{C}$, respectively. Sucrose and Yeast extract at $1 \%$ concentration was found to be the most preferred carbon and nitrogen source for cellulase production by $P$. ostreatus. The optimum working $\mathrm{pH}$ and temperature of cellulase were found to be 4 and $30^{\circ} \mathrm{C}$, respectively. Generally, cellulases are stable and active in a temperature range of $20-50^{\circ} \mathrm{C}$. These characteristics hopefully would make this enzyme potentially attractive in a variety of industrial applications like animal feed treatments. There was a linear relation between cellulase and its substrate concentration; there is an increase in activity with increasing substrate concentration. The relationship between the rate of reaction and substrate concentration depends on the affinity of the enzyme for its substrate. P. ostreatus synthesized cellulases were used for saccharification of wheat straw, Eucalyptus bark, and Teff straw. The cellulolytic enzyme complex when incubated with the agro-waste released sugars.

\section{Recommendations}

- Further study is recommended at a molecular level to enhance the production of cellulase from P. ostreatus for animal feed processing and other possible industrial application.

- This study is also strongly recommended that researches have to be done on large scale production, further purification and characterization of cellulase from P. ostreatus.

- Optimization of P. ostreatus cellulase production would be done, to be used in industrial level.

- Further study should be made to optimize the potential of P. ostreatus for production of other ligninolytic enzymes.

\section{Compliance with ethical standards}

\section{Acknowledgments}

The authors would wish to acknowledge Holetta Agricultural Research Center and National Biotechnological Research Laboratory laboratory technical assistance for their support and providing infrastructural facility to review this study

\section{Disclosure of conflict of interest}

The authors declare that they have no competing interests

\section{References}

[1] AbdullahA. Cellulase enzyme system. Journal of Biochemistry. 2006; 23: 1223- 1228.

[2] Ali UF, Saad El-Dein HS. Production and Partial Purification of Cellulase Complex byAspergillus niger and A. nidulans Grown on Water Hyacinth Blend. J Appl Sci Res. 2008; 4: 875-891.

[3] Baig MMV, Mane VP, More DR, Shinde LP, Baig MIA. Utilization of Agricultural Waste of Banana: Production of Cellulases by Soil fungi, Journal of Environmental Biology. 2003; 24: 173 -176.

[4] Beguin P, Aubert JP. The biological degration of cellulose. FEMS Microbiology Rev. 1994; 13: 25-28.

[5] Cen P, Xia L. Production of Cellulase by Solid-State Fermentation. Advances in Biochemical Engineering. 1999. 
[6] Da Silva R, Lago ES, Merheb CW, Macchione MM, Park YK, Gomes E. Production of xylanase and CMCase on solid state fermentation in different residues by Thermoascus aurantiacus miehe. Brazil Journal of Microbiology. 2005; 36(3): 235-241.

[7] Demir H, gogus N, tari c, heerd d, lahore m. Optimization of the process parameters for the utilization of orange peel to produce polygalacturonose by solid-state fermentation from Aspergillus sojae mutant strain. Turkish Journal of Biology. 2012; 36: 394-404.

[8] Ghose TK. Measurement of cellulase activities. Pure and Applied Chemistry. 1987; 59: 257-268.

[9] Immanuel G, Akila Bhagavath CM, Iyapppa Raj P, Essakking P, Palavessam A. Production and partial purification of cellulase by Aspergillus niger and A. fumigatus fermented in coir waste and saw dust. International Journal for Microbiology. 2007; 3: 1-17.

[10] Immanuel G, Akila Bhagavath CM, Iyapppa Raj P, Essakking P, Palavessam A. 2007.

[11] Jemaneh Zeleke. Xylanase production by the termite associated fungus, Termitomyces sp. and its role inthe termite nest. M.Sc. Thesis. Addis Ababa University. 2012.

[12] Kamra P, Satyanarayana T. Xylanase Production by the Thermophilic Mold Humicola lanuginosa in Solid State Fermentation. Applied Biochemistryand Biotchnology. 2004; 119: 145-158.

[13] Koomnok C. Selection of cellulose producing thermophilic fungi. 31st congress on Science and Technology of Thailand. 2005.

[14] Kuhad RC, A Singh. Enhanced production of cellulases by Penicillium citrinum. 1993.

[15] Kumar A, Kanwar SS. Lipase production in solid-state fermentation (SSF): recent developments and biotechnological applications. Dynamics Biochemistry, Process Biotechnology Molecular Biology. 2012. 6(1): 1327.

[16] Lederberg J. Cellulases. Encyclopaedia of Microbiology. 1992; 1.

[17] Lee BH, Kim BK, Lee YJ, Chung $\mathrm{CH}$, Lee JW. Industrial scale of optimization for the production of carboxymethylcellulase from rice bran by a marine bacterium, Bacillus subtilis subsp. subtilis A-53, Enzyme and Microbial Technology. 2010; 46(1): 38-42.

[18] Lee RL, Paul JW, van Zyl WH, Pretorius IS. Microbial cellulose utilization: Fundamentals and biotechnology. Microbiology and Molecular Biology Review. 2002; 66: 506-577.

[19] Lynd lr, weimer pj, zyl whv, pretorious IS. Microbial cellulose Utilization: Fundamentals and Biotechnology. Microbiology and Molecular Biology Reviews. 2002; 66: 506-577.

[20] Mandels M, Reese ET. Induction of cellulase in Trichoderma viride as influenced by carbon sources and metals. J. Bacteriology. 1957; 73: 269278.

[21] Naraian R, D Singh, A Verma, SK Garg. Studies on in vitro degradability of mixed crude enzyme extracts produced from Pleurotus spp. Journal of Environmental Biology. 2010; 31(6): 945-951.

[22] NaveenKumar KJ, Thippeswamy B. Isolation and screening of potential cellulolytic fungi from Areca nut husk waste, International journal current science. 2013; 8: 125-132.

[23] Nochure SV, Roberts MF, Demain AI. True cellulases production by Clostridium thermocellum grown on different carbon sources, Biotech. Letters. 1993; 15: 641646.

[24] OECD. Consensus Document on the Biology of Pleurotus spp. (Oyster Mushroom). Organisation for Economic Cooperation and Development: Environment, Health and Safety Publications Series on Harmonisation of Regulatory Oversight in Biotechnology. 2005; 34: 10-15.

[25] Pandey A, Ashakumary L, Selvakumar P, Vijyalakshmi KS. Influence of water activity on growth and activity of Aspergillus niger for glycoamylase production in solid-state fermentation. World Journal of Microbiologyand Biotechnology. 1994; 10: 485-486.

[26] Papaspyridi LM, Aligiannis NE, Chris-takopoulos Topakas P, Skaltsounis AL, Fokialakis N. Submerged fermentation of the edible mushroom Pleurotus ostreatus in a batch stirred tank bioreactor as a promising alternative for the effective production of biometabolites Molecules. Journals of Biomedical and Biotechnology. 2012; 17: 2714-2724. 
[27] Polyanna NH, Porto TS, Moreira KA, Pinto GAS, Cristina MSM, Ana LFP. Cellulase production by Aspergillus japonicus URM5620 using waste from castor bean Ricinus communis L. under. 2011.

[28] Sherief AA, Tanash AB, Atia N. Cellulase production by Aspergillus fumigatus grown on substrate of rice straw and wheat bran. Research Journal. of Microbiology. 2010; 5: 99-211.

[29] Singhania RR, Sukumaran RK, Pillai A, Prema P, Szakacs G, pandey A. Solid state fermentation of lignocellulosic substrates for cellulase production by Trichoderma reesei NRRL 11460. Indian Journal of Biotechnology. 2006; 5: 332-336.

[30] Stamets P. Chapter 1: The Role of Mushrooms in Nature. Growing Gourmet and Medicinal Mushrooms, Ten Speed Press, Berkeley California, USA. 1993; 21-27.

[31] Teather RM, Wood PJ. Use of congo red-polysaccharide interactions in enumeration and characterization of cellulolytic bacteria from the bovine rumen. App. Environ. Microbiol, 43(4): 777-780Tony C., Charles G., Georges F., 2005. Xylanases, xylanase families and extremophilic xylanases . FEMES Microbiobl. Rev. 1987; 29: 3-23.

[32] Tesfaye Kumsa, Madsen JO, Azage Tegegne. Manure Production, handling and use around Holetta Agricultural Research Center Proceedings of the 13th annual conference of the Ethiopian Society of Animal Production (ESAP). August 25-27, Addis Ababa, Ethiopia. 2004.

[33] Toor Y, Ilyas U. Optimization of cellulase production by Aspergillus ornatus by the solid state fermentation of Cicer arietinum. Am. J. Res. Commun. 2014; 2(1): 125-141.

[34] Tsujiyama S, Ueno H. Performance of wood-rotting fungi based enzymes on enzymic saccharification of rice straw. Journal of Science in Food and Agriculture. 2013; 93: 2841-2848.

[35] Vinod Kumar Nathan, Mary Esther Rani, Gunaseeli Rathinasamy, Kannan Narayanan Dhiraviam, Sridhar Jayavel. Process optimization and production kinetics for cellulase production by Trichoderma viride VKF3 SpringerPlus. 2014; 3: 92.

[36] Watanabe H, Tokuda G. Animal cellulases. Cell Molecularand Life Science. 2001; 58: 1167-1178.

[37] Youssef GA, Berekaa MdM. Improved production of Endoglucanases by Aspergillus terreus; application of Plackett. 2009. 